AL-IQTISHOD: Jurnal Pemikiran dan Penelitian Ekonomi Islam

E-ISSN: 2745-85I2 P-ISSN: 2407-6600

Volume 9 Issue 2 Juli 202I | Page: 39-54

DOI: $\operatorname{xxxxxxxxxxxxxxxx}$

\title{
Penerapan Digital Banking Bank Syariah Sebagai Upaya Customer Retantion Pada Masa Covid-I9
}

\section{Rika Mawarni}

Universitas Islam Negeri Raden Intan Lampung

Email : rikaamawarnii@gmail.com

\author{
Muhammad Iqbal Fasa' \\ Universitas Islam Negeri Raden Intan Lampung \\ Email : MuhammadIqbalFasa@ymail.com
}

Suharto

Universitas Islam Negeri Raden Intan Lampung

Email : Prof.suharto@radenintan.ac.id

Abstract: This paper seeks to provide an overview of the application of digital banking by Islamic banks as one of the steps in maintaining their customers during the Covid-I9 pandemic. The economic slowdown due to Covid-I9 has reduced payment activities, but has accelerated the adoption of digital financial technology. The method used in this study is a qualitative descriptive analysis technique, which seeks to describe the condition of digital banking in Islamic banks during the Covid-I9 pandemic where all data is generated and presented in the form of descriptions. The results of this study are Islamic banks trying to retain customers by optimizing the application of digital banking in their operations during the Covid-I9 pandemic. In line with the widespread use of digital instruments during the pandemic, digital economic and financial transactions continue to grow. In December 2020, the volume of digital banking transactions reached 513.7 million transactions, or grew $41.53 \%$ (yoy) with the value of digital transactions reaching Rp2,775.5 trillion, or growing $13.91 \%$ (yoy).

Keywords: Digital Banking, Customer Retantion, Covid-I9.

Abstrak: Penelitian ini berusaha untuk memberikan gambaran mengenai penerapan digital banking yang dilakukan bank syariah sebagai salah satu langkah dalam mempertahankan nasabahnya dimasa pandemi covid-19 ini. Perlambatan ekonomi akibat Covid-I9 menurunkan aktivitas pembayaran, namun mendorong akselerasi adopsi teknologi keuangan digital. Metode yang digunakan dalam penelitian ini adalah teknik analisis deskriptif kualitatif, yang berusaha memaparkan kondisi perbankan digital pada bank syariah dimasa pandemi covid-I9 dimana seluruh data yang dihasilkan dan disajikan berbentuk deskripsi. Hasil dari penelitian ini bank syariah berupaya untuk mempertahankan nasabah dengan mengoptimalkan penerapan digital banking dalam operasionalnya dimasa pandemi covid-I9 ini. Sejalan dengan maraknya penggunaan instrumen digital dimasa pandemi, membuat transaksi ekonomi dan keuangan digital terus tumbuh. Pada Desember 2020, volume transaksi digital banking mencapai 513,7 juta 
transaksi, atau tumbuh 41,53\% (yoy) dengan nilai transaksi digital mencapai Rp2.775,5 triliun, atau tumbuh $13,91 \%$ (yoy).

Kata Kunci: Digital Banking; Customer Retantion; Covid-I9 
Rika Mawarni, dkk.

\section{A. Pendahuluan}

Dalam masa pandemi, pemerintah Indonesia memperhatikan tiga sektor, yaitu kesehatan, sektor riil dan perbankan. Pandemi Covid-19 menjadi permasalahan bagi perbankan, karena bisa menghasilkan permasalahan di sektor riil atau dunia usaha yang berpotensi menimbulkan persoalan di sektor perbankan, dikarenakan sektor perbankan merupakan lembaga intermediasi atau perantara yang mendukung kebutuhan dana investasi bagi dunia usaha. Perbankan syariah di Indonesia menghadapi sejumlah tantangan di tengah wabah Covid-19. Menurut Pengamat Ekonomi Syariah Adiwarman Karim menyampaikan kondisi industri Perbankan Syariah bisa lebih dulu memburuk dari pada industri bank konvensional.(Ilhami \& Thamrin, 202I)

Beberapa sektor usaha terdampak oleh wabah pandemi virus Covid-19 termasuk sektor perbankan syariah. Oleh karena itu, agar sektor perbankan syariah dapat tetap eksis di tengah pandemi virus korona, maka perbankan syariah harus melakukan mitigasi risiko secara cermat, dan menggunakan strategi kreatif menghadapi kondisi yang serba tidak menentu saat ini. Jika bank syariah ingin keluar dari kondisi keterpurukan, maka sudah sepatutnya bank syariah tidak dapat menggunakan metode atau cara-cara lama dalam memasarkan layanan produk dan jasanya. Salah satu strategi yang dapat dilakukan bank syariah adalah dengan adanya digital banking. Layanan produk dan jasa harus dikonversi menjadi digital banking. Proses tersebut harus berjalan bertahap dan inisiasinya dilakukan secara terus menerus. Namun, tidak semua produk dan jasa harus menggunakan digital banking, terdapat bisnis inti yang masih membutuhkan fungsi oleh unsur manusia. Terdapat beberapa fungsi yang melibatkan unsur manusia, sehingga keberadaannya tidak dapat digantikan oleh digital banking. Salah satu peran tersebut adalah aktivitas pendampingan dan konsultasi bisnis. Misalnya ketika nasabah bank yang bisnisnya terdampak akibat pandemi Covid-19, maka ia akan mendapatkan pendampingan dan konsultasi bisnis dari tenaga pemasar bank.(Habibah, 2020)

Volume. 9/No. 2/Juli 202I A1-Iqtishod|39 
Penerapan Digital Banking Bank Syariah ...

Perbankan merupakan lembaga intermediasi keuangan yang bertugas mengumpulkan dana dari masyarakat (nasabah) dan menyalurkanya kepada masyarakat. Bank yang merupakan lembaga kepercayaan masyarakat untuk menyimpan uangnya dan mempercayakan bank dalam mengelola keuangannya. Dalam memenuhi kebutuhan nasabah seta meningkatkan pertumbuhan perbankan dan keuangan perbankan, maka bank berupaya untuk memaksimalkan pelayanan melalui perbankan digital yang dimana pada era modern saat ini dapat menjadikan alternatif utama bagi pengguna mobile banking. Dalam melakukan penerapan perbankan digital ini maka bank syariah harus mampu merubah model pemasaran dan model manajemen bank syariah. Tantangan bagi bank syariah dalam mengembangkan perbankan digital yaitu keengganan nasabah yang diakibatkan oleh pengalaman buruk. Untuk itu, pengembangan teori pemasaran layanan dalam perbankan digital membutuhkan pemahaman preferensi pelanggan dari kepuasan dan loyalitas pelanggan.(Vebiana, 2018)

Salah satu tujuan dalam melakukan digitalisasi bank ini adalah untuk mencapai kepuasan pelanggan. Kepuasan nasabah merupakan hal yang paling penting didalam industri perbankan yang merupakan sektor jasa. Nasabah akan dengan mudah berpindah kepada bank lain apabila tidak mendapatkan apa yang diharapkan. Fakta tersebut mengharuskan industri perbankan untuk kreatif dalam menciptakan keunggulan bersaing di tengah persaingan ketat memperebutkan nasabah dan menjaga kepuasannya sehingga menjadi nasabah yang loyal dan mampu meningkatkan laba bagi suatu perbankan, Keunggulan bersaing itu harus dilihat oleh nasabah sebagai keunggulan nasabah (customer's advantage). Sehingga bank harus fokus pada pembentukan keunggulan nasabah yang dapat memberikan nilai dan kepuasan tertinggi yang berujung pada penggunaan layanan ulang dan akhirnya mampu meningkatkan profitabilitas bank yang tinggi juga. Untuk mencapai hal tersebut langkah utama pertama yang harus dilakukan oleh bank adalah mengukur tingkat kualitas layanan yang telah diberikan.(Asti Marlina, 20I8)

40| A1-Iqtishod Volume. 9/No.2/Juli 202I 
Rika Mawarni, dkk.

Terlepas dari berbagai risiko masa depan yang akan dihadapi industri ini terhadap wabah Covid, digitalisasi produk dan layanan bank syariah harus dilaksanakan dengan cepat dan secara responsif. Penerapan teknologi digital akan mengikuti teori ekonomi yang menjelaskan hal itu kemajuan teknologi mengarah pada peningkatan produktivitas dan mendorong efisiensi perusahaan. Perusahaan yang efisien dan produktif akan meningkatkan kemampuannya untuk bersaing dan mendominasi pasar. Namun dalam praktiknya, tentunya masing-masing bank memiliki cara pandangnya masing-masing terkait urgensi tersebutdari fenomena perbankan digital. Hal ini tentu saja mempengaruhi daya saing mereka di mana bank menempatkan strategi digital sebagai strategi penting. Penerapan sistem digital banking pada perbankan syariah dinilai kurang agresif dibandingkan perbankan konvensional. Sistem perbankan dengan teknologi digital bisa tampil fungsi penting bank sebagai lembaga perantara keuangan dan jasa keuangan penyedia dan di luar sebagai penasihat keuangan untuk pelanggan mereka.(Azizah et al., 2020) Oleh karena itu, penelitian ini berusaha untuk memberikan gambaran mengenai penerapan digital banking yang dilakukan bank syariah sebagai salah satu langkah dalam mempertahankan nasabahnya (Customer Retantion) dimasa pandemi covid-I9 ini.

\section{B. Kajian Pustaka}

\section{Peluang dan Tantangan Penerapan Digital Banking}

Bersamaan dengan pemanfaatan teknologi digital, perbankan syariah juga fokus pada layanan utamanya, Namun, tidak mudah untuk merubah seluruh tatanan dan sistem perbankan syariah dalam sesaat. Butuh uji coba pada kelayakan dan dampaknya pada sejumlah bidang. Tentunya dengan mengandalkan pemanfaatan teknologi digital 4.0 ini, bank syariah akan berhadapan dengan dua kondisi sekaligus, yaitu peluang dan tantangan. Peluangnya adalah perbank syariah berkesempatan untuk membangun SDM yang kreatif dan inovatif. Selain itu, penawaran khusus yang dirancang dengan landasan syariat Islam, akan mudah

Volume. 9/No. 2/Juli 202I A1-Iqtishod|4I 
Penerapan Digital Banking Bank Syariah ...

diterima di kalangan masyarakat, khususnya Muslim. Dengan adanya teknologi digital ini juga akan mendorong terjalinnya kerjasama dan daya saing yang sehat antar perbankan syariah dan konvensional.(Husna, 2020)

Dengan adanya kemajuan teknologi yang menyebabkan perubahan informasi analog menjadi informasi digital, masyarakat lebih memilih menggunakan informasi digital dengan alasan :

I. Mudah untuk dicari, ditelusuri, diakses dan digunakan sesuai dengan kebutuhan pengguna

2. Mudah untuk diproduksi, dikirim, diterima, disaring, diperbaharui berdasarkan kemampuan pengguna

3. Format penulisan dan isi pesan yang dikirim sama dengan format penulisan dan isi pesan yang diterima

4. Tidak terhambat oleh jarak yang jauh, perbedaan bahasa dan perbedaan waktu

5. Pengiriman dan penerimaan pesan sangat cepat dan murah

6. Mudah untuk disimpan dan diolah sehingga tidak memerlukan ruang penyimpanan yang besar

7. Mudah diaplikasikan dalam berbagai media karena format isi dari informasi digital akan sama, antara device yang satu dengan device yang lainnya.(Asti Marlina, 2018)

Tantangan bagi ekonomi Syariah, bagaimana membuat konsumen/ masyarakat tertarik untuk melakukan aktivitas perekonomian syariah, baik itu wirausaha syariah maupun melalui perbankan Syariah. Tantangan ekonomi Syariah yang lain adalah perbankan Syariah dan atau wirausaha Syariah harus mampu membuktikan bahwa kegiatan perekonomian yang dilakukan senilai dengan transaksi yang telah dilakukan karenanya kualitas barang menjadi urgent sehingga konsumen Muslim tidak merasa dibohongi ataupun kecewa. Hal ini sangat penting sebab dalam sistem ekonomi digital ini bentuk fisik produk secara langsung dan nyata, pembeli/ konsumen tidak bisa melihat dan mengetahuinya.(Maharani \& 
Ulum, 2020) Nasabah perbankan pada umumnya, dan perbankan digital pada khususnya dihadapkan dalam posisi yang serba sulit, oleh karena kepentingan dan perlindungan nasabah selaku konsumen (jasa) banyak dirugikan. Kasus-kasus penggelapan simpanan dana nasabah pada bank, kasus pembobolan kartu kredit, data pribadi dan nomor Personal Identification Number (Nomor PIN) yang seharusnya adalah rahasia) ternyata sudah diperjualbelikan, dan lain sebagainya.(Gaib, 2020)

Tantangan transformasi pemanfaatan teknologi digital lebih dari sekedar menyediakan layanan online dan mobile banking, perlu berinovasi dalam menggabungkan teknologi digital dengan interaksi nasabah, dalam hal ini temuantemuan teknologi baru tersebut haruslah mempermudah dan memberikan kenyamanan bagi pengguna dalam mengakses layanan perbankan. Salah satunya adalah perbankan digital yang menggambarkan proses virtual penunjang seluruh layanan yang akan berdampak positif pada pertumbuhan bisnis secara umum. Sehingga, strategi digitalisasi harus selalu dikembangkan oleh Bank. Digitaliasi mengharuskan bank syariah melakukan pembaharuan layanan, mengingat peralihan dunia perbankan menjadi digital dapat meningkatkan efesiensi proses kerja dan meningkatkan kualitas layanan nasabah, dengan melakukan digitalisasi, bank sudah melakukan investasi jangka panjang untuk masa depan, dan diproyeksikan layanan digital menjadi salah satu pendorong utama pertumbuhan industri perbankan secara berkelanjutan.(Tahliani, 2020)

Peluang dan tantangan di era digital akan dirasakan oleh semua sektor termasuk industri keuangan dan juga industri perbankan syariah. Untuk mengatasi berbagai persoalan di atas, setidaknya ada beberapa langkah yang dapat dilakukan oleh perbankan syariah sebagai ikhtiar untuk mengembangkan digital banking tersebut: Pertama, pengalaman konsumen, yakni perusahaan-perusahaan digital harus memberikan kesan terbaik kepada konsumen dalam menggunakan jasanya. Sebab, konsumen di dunia digital sangat mudah berpaling ke perusahaan- 
Penerapan Digital Banking Bank Syariah ...

perusahaan lain. Kedua, cyber security, yaitu perbankan bersama- sama pemerintah harus bekerja sama dalam memberikan keamanan bagi transaksi transaksi yang dilakukan. Ketiga, menghubungkan online dengan offline. Keempat, perusahaan juga harus menggunakan analisis berbasis data untuk menentukan kebutuhan, perilaku, dan keinginan konsumen. Kelima, berbagai perusahaan dan pemerintah harus sudah mulai membangun DNA digital. Jadi, pemerintah dan perusahaan harus mengeluarkan regulasi yang mendukung digitalisasi.(Dz., 2018)

Dengan adanya digital bank diharapkan bank dapat mempermudah dalam menyimpan dan menganalisa data nasabah. Sehingga dapat membantu bank untuk menjaga hubungan dengan konsumen, mengatasi keluhan konsumen dengan lebih baik, serta dapat mengembangkan produk atau layanan yang lebih tepat dengan lebih cepat, murah, jelas dan transparan bagi konsumen. Bank lebih efisien karena ridak lagi berinvestasi pada kantor cabang serta nasabah tidak perlu repot ke kantor cabang misalnya untuk transfer uang ke keluarga yang berbeda daerah.

\section{Metode Penelitian}

Metode yang digunakan dalam penelitian ini adalah teknik analisis deskriptif kualitatif, yang berusaha memaparkan kondisi perbankan digital pada bank syariah dimasa pandemi covid-I9 dimana seluruh data yang dihasilkan dan disajikan berbentuk deskripsi yaitu berupa gambaran tentang hasil dari penelitian. Teknik pengumpulan data yang digunakan antara lain pendekatan studi literatur jurnal dan artikel online maupun cetak, dan kepustakaan yang berkaitan dengan penelitian ini.

\section{Hasil dan Pembahasan}

\section{Kondisi Perbankan Syariah Pada Masa Pandemi Covid-19}

Covid-19 atau disebut Coronavirus Disease 2019 merupakan penyakit menular yang dapat menyebabkan penyakit paru-paru yang cukup serius. Kasus Covid-19 ditemukan pertama kali di Tiongkok pada November 2019. Covid-I9 diketahui sebagai penyakit menular yang disebabkan oleh virus baru dengan tingkat 
Rika Mawarni, dkk.

penyebaran yang sangat cepat. Seperti yang dilaporkan oleh Organisasi Kesehatan Dunia (WHO), total kasus Covid-I9 yang terkonfirmasi di seluruh dunia adalah sebanyak 3.II6.398 kasus dengan jumlah kematian 2I7.I53 jiwa (29 April 2020). Indonesia adalah negara dengan jumlah kematian terbesar akibat Covid-I9 di antara negara-negara ASEAN lainnya.(Sumadi, 2020)

Berikut adalah statistik kasus Covid-I9 di Indonesia pada tahun 2020 diman terjadi peningkatan kasus yang tinggi secara signfikan di masyarakat dan memberikan dampak bagi kehidupan dan perekonomian Indonesia.

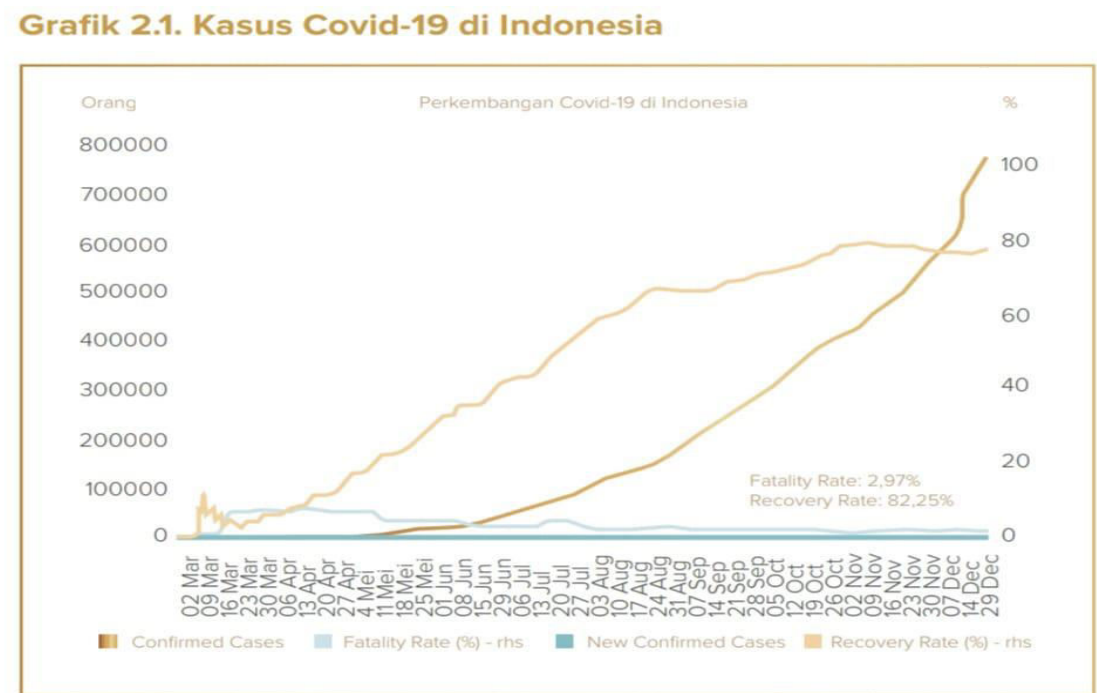

Sumber: Gugus Tugas Percepatan Penanganan Covid-19, dialah

\section{Sumber : Laporan Tahunan Perbankan 2020}

Covid-19 memberikan dampak signifikan terhadap perkembangan ekonomi dunia. Pandemi Covid-I9 adalah tantangan bagi dunia bisnis, termasuk industri jasa keuangan perbankan. Berdasarkan pada data statistik perbankan Syariah pada Januari 2020, terdapat I.922 jumlah jaringan kantor Bank Umum Syariah. Cabang yang tersebar di berbagai wilayah di Indonesia yang didominasi oleh Pulau Jawa. Sejalan dengan wilayah terbanyak ditemukan Covid-I9 yaitu di pulau Jawa (Statistik Perbankan Syariah, Januari 2020). Ini menunjukkan bahwa 
Penerapan Digital Banking Bank Syariah ...

sebagian besar dari kantor Bank Syariah berada di wilayah zona merah.(Mardhiyaturrositaningsih, 2020)

Sebelum adanya penyebaran virus corona di Indonesia, perbankan syariah diharapkan tetap mencatatkan rekor pertumbuhan double- digit. Akan tetapi, dampak dari penyebaran Covid-19 saat ini perbankan syariah harus mulai merevisi kembali target pertumbuhan mereka. Perbankan syariah juga diharapkan mampu memberikan solusi-solusi atau strategi terbaik kepada para nasabahnya seperti restrukturisasi, penambahan jangka waktu pembiayaan, ataupun memberikan masa tenggang 3-6 bulan kedepan. Sehingga nasabah yang terkena dampak dari virus ini bisa merasakan kehadiran bank yang sesuai syariah sebagai solusi dari krisis perekenomian. Perbankan syariah juga harus melihat permasalahan penyebaran virus ini sebagai tantangan yang harus dirubah menjadi sebuah kesempatan untuk berbenah khususnya dari aspek layanan digital. Apalagi ketika WHO menyebutkan bahwasanya penyebaran virus ini bisa menyebar melalui uang kertas, bahkan ada negara yang menyemprot uang kertasnya agar tidak terjadi penyebaran melalui media ini. Pembayaran digital yang mampu memudahkan para nasabah melakukan seluruh transaksi dalam satu aplikasi merupakan sebuah keharusan yang dimiliki perbankan syariah.(Habibah, 2020)

\section{Perkembangan Digital Banking di Dunia Perbankan}

Sejak layanan perbankan online dilakukan oleh Stanford Federal Credit pada tahun 1994, secara online perbankan menyebar dengan cepat ke seluruh dunia. Internet banking sudah berkembang dan diterapkan di Indonesia pada tahun 1998 oleh BII dan mobile banking diterapkan oleh BCA pada tahun 200I, mobile banking Islami diterapkan oleh BCA Syariah pada tahun 2014 dan diikuti oleh bank lain. Transaksi menggunakan digital Perbankan semakin masif setelah pertumbuhan Start- $U_{p}$ Business di tahun 2010 dan terus berkembang hingga sekarang. Perkembangan teknologi, perubahan perilaku konsumen, dan tren 
Rika Mawarni, dkk.

bisnisPersaingan menjadi faktor pendorong bagi bank untuk terus berinovasi, khususnya bank syariah yang memiliki dua aturan dalam menjalankan bisnisnya (hukum Islam dan peraturan pemerintah). (Riza, 2019)

Pada dekade berikutnya, pada tahun 2010-an dan seterusnya perbankan digital memanfaatkannya menjadi salah satu poin penting yang membuat bank bisa bertahan dalam krisis ekonomi kedua. Fase ini mendorong bank untuk berinvestasi lebih banyak dalam proyek digital, menciptakan gelombang kedua digitalisasi di Indonesia. Beberapa bank mulai menggunakan berbagai platform media sosial untuk menyampaikan, memperkenalkan, dan mensosialisasikan berbagai fitur produk yang bermanfaat bagi pelanggannya seperti: membuka saluran layanan pengaduan pelanggan; dan mendorong interaktif dua arah komunikasi, sehingga pelanggan merasa lebih terhubung dan dihormati. Strategi ini menghilangkan paradigma bahwa layanan perbankan hanya dapat diakses melalui konvensional ranting. Tuntutan digitalisasi perbankan juga diperkuat dengan pergeseran bisnis kepemilikan, yang saat ini didominasi oleh generasi milenial, yang lebih memilih kenyamanan transaksi online dan seluler.(Winasis et al., 2020)

Seiring dengan perkembangan teknologi, digital banking mulai mewarnai setiap aktivitas keuangan nasabah. Kemudahan yang diberikan membuat nasabah merasa diuntungkan. Namun sayangnya, masih sebagian masyarakat Indonesia saja yang menikmati layanan perbankan digital ini. Berdasarkan data dari lembaga keuangan dunia menyatakan hanya 54\% dari masyarakat Indonesia yang tersentuh layanan perbankan. Generasi millenial sekarang berfikir bahwa ATM, mobile banking, internet banking, sms banking dan yang lainnya adalah hal yang sudah biasa, atau hal yang mainstream. Sekarang masyarakat berfikir, bagaimana masyarakat ingin membuka rekening, menabung, serta mengajukan kredit atau pinjaman dan layanan perbankan lainnya, tanpa harus menghadirkan diri secara fisik atau datang langsung ke bank bersangkutan. Hal inilah yang ditangkap sebagai potensi dan kesempatan oleh bank, untuk meningkatkan minat calon 
Penerapan Digital Banking Bank Syariah ...

nasabah dengan memberikan layanan yang nasabah inginkan sehingga loyal terhadap bank.(Kholis, 2018)

\section{Penerapan Digital Banking Sebagai Upaya Customer Retantion Pada Masa Covid-} 19

Ditengah disrupsi teknologi dewasa ini, perbankan syariah juga harus berkompetisi tidak hanya dengan perbankan konvensional namun juga dengan perusahaan teknologi finansial (financial technology / fintech). Era banking 4.0 telah merevolusi dan mentransformasi sektor keuangan syariah sehingga inovasi bank syariah dalam hal layanan teknologi kepada konsumen menjadi suatu hal yang mutlak. Perubahan perilaku konsumen menuntut perbankan untuk lebih adaptif dengan teknologi digital. Karena jika tidak, maka perbankan syariah akan bisa ditinggal nasabah dan beralih ke institusi keuangan syariah lain seperti fintech syariah. Menurut survey dari PWC (2018) menunjukkan hanya I4 persen dari bank syariah yang mengatakan bahwa tujuan dari digitalisasi adalah untuk meningkatkan pendapatan dari bank syariah. Padahal adanya digitalisasi perbankan syariah dapat berdampak pada efisiensi biaya yang dikeluarkan sehingga bisa meningkatkan pendapatan bank syariah. Bank syariah dewasa ini tidak bisa hanya mengandalkan outlet fisik saja namun juga harus menjangkau nasabahnya melalui layanan digital seperti internet banking dan mobile banking.(Kementerian PPN/ Bappenas, 2020)

Terdapat dua macam strategi yang dikenal di dalam dunia marketing, yakni strategi mencari pelanggan baru dan strategi mempertahankan pelanggan yang sudah ada (customer retention). Kedua strategi tersebut dapat dilaksanakan secara bersamaan, tetapi strategi mempertahankan pelanggan (customer retention) selayaknya mendapatkan perhatian yang lebih besar. Ini berarti, organisasi harus selalu berupaya agar para pelanggannya selalu merasa puas dan melakukan pembelian ulang. organisasi perlu menyelaraskan kompetensi, teknologi dan 
Rika Mawarni, dkk.

sumber daya yang dimiliki dengan kebutuhan dan keinginan pelanggan yang dinamis ini.(Zulkifli, 20I2) Customer retention adalah kegiatan pemasaran dalam mempertahankan pelanggan yang dilakukan oleh perusahaan melalui strategi terencana, fokus pada pengembangan kegiatan pemasaran, membangun hubungan, perawatan pelanggan serta menciptakan loyalitas pelanggan. Dengan disadari bahwa peran dari customer retention sangatlah penting untuk meningkatkan keuntungan dan tujuan bersama antara perusahan dan pelanggan begitupun sebaliknya.(Sigalingging, 2017)

Menurut peraturan Otoritas Jasa Keuangan (OJK) nomor I2 /POJK.03/2018 Tentang Penyelenggaraan Pelayanan Perbankan Digital oleh Bank Umum, dimana pengertian digital banking adalah pelayanan bagi perbankan elektronik yang dikembangkan dalam rangka memaksimalkan pemanfaatan data nasabah dalam rangka melayani dan memberikan informasi kepada nasabah secara lebih mudah, cepath, dan sesuai dengan kebutuhan (customer experience), serta dapat dijalankan dengan mandiri sepenuhnya oleh pihak nasabah, dengan memperhatikan aspek berbagai pengamanan.(Otoritas Jasa Keuangan, 20I8) Penerapan digital banking di Indonesia dibuktikan dengan adanya berbagai layanan yang dapat memudahkan nasabah antara lain : Pertama, adanya Internet Banking. Kedua, adanya Phone Banking. Ketiga, adanya SMS Banking. Keempat, adanya Mobile Banking. Bank dapat bekerja sama dengan operator seluler, sehingga dalam SIM Card (kartu chips seluler) Global for Mobile communication (GSM) sudah dipasangkan program khusus untuk bisa melakukan transaksi perbankan. Proses transaksi nasabah akan lebih mudah pada mobile banking dibandingkan dengan SMS Banking.(OJK RI, n.d.)

Perlambatan ekonomi yang diakibatkan oleh pandemi Covid-I9 menurunkan aktivitas pembayaran, namun mendorong terjadinya akselerasi adopsi teknologi keuangan digital. Pertumbuhan uang tunai terkontraksi sejalan penerapan PSBB yang menurunkan mobilitas dan kebutuhan transaksi tunai 
Penerapan Digital Banking Bank Syariah ...

masyarakat. Transaksi pembayaran nontunai baik melalui ATM, Kartu Debet, Kartu Kredit, dan Uang Elektronik (UE) mengalami kontraksi, transaksi digital banking dan volume transaksi pembayaran melambat. Perkembangan positif terlihat pada peningkatan preferensi dan akseptasi masyarakat terhadap penggunaan platform dan instrumen keuangan digital, seperti e-commerce, untuk pemenuhan kebutuhan sehari-hari.

Transaksi pembayaran tunai dan non tunai dalam tren pemulihan pada semester II seiring membaiknya aktivitas ekonomi. Pada Desember 2020, UYD kembali meningkat I3,25\% (yoy). Nilai transaksi pembayaran non tunai dengan ATM, Kartu Debet, dan Kartu Kredit pada Desember kembali tumbuh positif I,36\% (yoy) setelah mengalami kontraksi pada bulan sebelumnya. Transaksi ekonomi dan keuangan digital terus tumbuh tinggi sejalan dengan semakin maraknya penggunaan platform e-commerce dan instrumen digital di masa pandemi, serta kuatnya preferensi dan akseptasi masyarakat akan digital. Hal ini terlihat dari nilai transaksi Uang Elektronik (UE) pada Desember 2020 yang tumbuh 30,44\% (yoy). Disamping itu, transaksi digital banking juga terus meningkat. Pada Desember 2020, volume transaksi digital banking mencapai 5I3,7 juta transaksi, atau tumbuh 4I,53\% (yoy) dengan nilai transaksi digital mencapai Rp2.775,5 triliun, atau tumbuh 13,91\% (yoy). Sementara itu, nominal transaksi e-commerce meningkat 19,55\% (yoy) pada triwulan III, sehingga secara keseluruhan tahun 2020 tumbuh 29,6\% (yoy) pada 2020, didukung dengan peningkatan preferensi dari masyarakat pada penggunaan platform digital dan strategi promosi sejumlah marketplace.(Bank Indonesia, 2020)

Pelayanan (service) bukan sebatas melayani, melainkan mengerti, memahami, dan merasakan. Dengan demikian, penyampaian dalam pelayanan akan mengenai heart share pelanggan. Kemudian hal tersebut dapat menumbuhkan loyalitas pelanggan terhadap suatu produk. Sehingga memberikan dampak positif bagi citra perusahaan. Tantangan transformasi pemanfaatan teknologi digital lebih 
Rika Mawarni, dkk.

dari sekedar menyediakan layanan online dan mobile banking, perlunya bank untuk berinovasi dalam menggabungkan teknologi digital dengan interaksi nasabah, dalam hal ini temuan-temuan teknologi baru tersebut haruslah mempermudah dan memberikan kenyamanan bagi pengguna dalam mengakses layanan perbankan syariah.(Sumadi, 2020)

\section{E. Simpulan}

Sebelum adanya penyebaran virus corona di Indonesia, perbankan syariah diharapkan tetap mencatatkan rekor pertumbuhan double- digit. Akan tetapi, saat ini perbankan syariah harus mulai merevisi kembali target pertumbuhan mereka disebabkan dampak dari penyebaran Covid-19. Perbankan syariah juga harus melihat permasalahan penyebaran virus ini sebagai tantangan yang harus dirubah menjadi sebuah kesempatan untuk berbenah khususnya dari aspek layanan digital. Sekarang masyarakat berfikir, bagaimana masyarakat ingin membuka rekening, menabung, mengajukan kredit atau pinjaman dan layanan perbankan lainnya, tanpa harus menghadirkan diri secara fisik di bank bersangkutan. Hal inilah yang ditangkap sebagai potensi dan kesempatan oleh bank, untuk meningkatkan minat calon nasabah menjadi nasabah di bank, memberikan layanan yang nasabah inginkan sehingga loyal terhadap bank.

Perlambatan ekonomi akibat Covid-I9 menurunkan aktivitas pembayaran, namun mendorong akselerasi adopsi teknologi keuangan digital. Pertumbuhan uang tunai terkontraksi sejalan penerapan PSBB yang menurunkan mobilitas dan kebutuhan transaksi tunai masyarakat. Pada Desember 2020, UYD kembali meningkat I3,25\% (yoy). Nilai transaksi pembayaran nontunai dengan ATM, Kartu Debet, dan Kartu Kredit pada Desember kembali tumbuh positif I,36\% (yoy) setelah mengalami kontraksi pada bulan sebelumnya. Transaksi ekonomi dan keuangan digital terus tumbuh tinggi sejalan dengan semakin maraknya penggunaan platform e-commerce dan instrumen digital di masa pandemi, serta kuatnya preferensi dan akseptasi masyarakat akan digital. Hal ini terlihat dari nilai transaksi Uang Elektronik (UE)

Volume. 9/No. 2/Juli 202I A1-Iqtishod|5I 
Penerapan Digital Banking Bank Syariah ...

pada Desember 2020 yang tumbuh 30,44\% (yoy). Disamping itu, transaksi digital banking juga terus meningkat. Pada Desember 2020, volume transaksi digital banking mencapai 5I3,7 juta transaksi, atau tumbuh 4I,53\% (yoy) dengan nilai transaksi digital mencapai Rp2.775,5 triliun, atau tumbuh 13,91\% (yoy). Sementara itu, nominal transaksi e-commerce meningkat 19,55\% (yoy) pada triwulan III, sehingga secara keseluruhan tahun 2020 tumbuh 29,6\% (yoy) pada 2020, didukung peningkatan preferensi masyarakat pada penggunaan platform digital dan strategi promosi sejumlah marketplace.

\section{F. Daftar Pustaka}

Asti Marlina, W. A. B. (2018). Digitalisasasi Bank Terhadap Peningkatan Pelayanan Dan Kepuasan nasabah bank. Jurnal Ilmiah Inovator, 7 I), I 4-34.

Azizah, N., Azhari, A. R., \& Wahyudi, R. (2020). Covid-I9 outbreak: Islamic banking challenges in Indonesia. Islam in World Perspectives Symposium, I(I), I34-I4I.

Bank Indonesia. (2020). Laporan tahunan 2020.

Dz., A. S. (2018). Inklusi Keuangan Perbankan Syariah Berbasis Digital-Banking: Optimalisasi dan Tantangan. Al-Amwal: Jurnal Ekonomi Dan Perbankan Syariah, IO(I), 63. https://doi.org/I0.24235/amwal.vIOiI.28I3

Gaib, D. N. (2020). Dinamika Hukum Perbankan Digital di Indonesia. In LEX ET SOCIETATIS (Vol. 7, Issue II). https://ejournal.unsrat.ac.id/index.php/lexetsocietatis/article/view/2 7366

Habibah, N. F. (2020). Tantangan Dan Strategi Perbankan Syariah Dalam Menghadapi Covid-19. Iqtishodiah, 2(I), I-9.

Husna, F. (2020). Wajah Ekonomi 4.0: Perbankan Syari’ah Digital, Peningkatan Daya Saing Dan Strategi Dakwah Islam Fathayatul. Idarotuna, 3(I), 59-70.

http://ejournal.uinsuska.ac.id/index.php/idarotuna/article/view/II328

Ilhami, \& Thamrin, H. (202I). Analisis Dampak Covid I9 Terhadap Kinerja 
Rika Mawarni, dkk.

Keuangan Perbankan Syariah Di Indonesia. Jurnal Tabarru': Islamic Banking and Finance, 4(I), 37-45. https://doi.org/I0.25299/jtb.202I.vol4(I).6068

Kementerian PPN/ Bappenas. (2020). Trend Konversi Ke Bank Syariah, Tingkatkan Efisiensi dan Produktifitas Bisnis. www.knks.go.id

Kholis, N. (20I8). Perbankan dalam era baru digital. Jurnal Economicus, I2(I), 8088.

Maharani, S., \& Ulum, M. (2020). Ekonomi Digital : Peluang Dan Tantangan Masa Depan Terhadap Ekonomi Syariah Di Indonesia. In Conference on Islamic Studies (CoIS) (Vol. 0, Issue 0). https://doi.org/I0.30659/COIS.VOIO.798I

Mardhiyaturrositaningsih, M. S. M. (2020). Dampak pandemi covid-I9 terhadap manajemen industri perbankan syariah: analisis komparatif. Jurnal Ekonomi Dan Manajemen, 2(I), I-IO.

OJK RI. (n.d.). Layanan Digital Banking .: SIKAPI :: Retrieved March I7, 202I, from https://sikapiuangmu.ojk.go.id/FrontEnd/CMS/Article/345

Otoritas Jasa Keuangan. (20I8). POJK Nomor I2/POJK.03/20I8 Tentang Penyelenggaraan Layanan Perbankan Digital Oleh Bank Umum. Ojk RI, I, I-55. http://www.ojk.go.id/id/kanal/iknb/regulasi/lembagakeuangan-mikro/peraturan-ojk/Documents/SAL-POJK PERIZINAN FINAL F.pdf

Riza, A. F. (2019). Customer acceptance of digital banking in Islamic bank : Study on millennial generation. Conference on Islamic Management, Accounting, and Economics (CIMAE) Proceeding, 2, 66-74.

Sigalingging, V. (2017). Pengaruh Relationship Marketing terhadap Customer Retention di Bank BNI Kantor Cabang Jakarta Kota. Utilitas, 3(I), 27-36.

Sumadi. (2020). Menakar Dampak Fenomena Pandemi Covid-I9 Terhadap Perbankan Syariah. Jurnal Hukum Ekonomi Syariah, 3(2), I45-I62.

Tahliani, H. (2020). Tantangan Perbankan Syariah dalam Menghadapi Pandemi Covid-19. Madani Syariah, 3(2), 92-II3. https://doi.org/I0.5I476/MADANISYARI'AH.V3I2.205

Vebiana, V. (2018). Perbankan Digital, Pengalaman Pelanggan, dan Kinerja Volume. 9/No. 2/Juli 202I A1-Iqtishod|53 
Penerapan Digital Banking Bank Syariah ...

Keuangan Bank Syariah. POLBAN, 9, 747-75 I.

Winasis, S., Riyanto, S., \& Ariyanto, E. (2020). Digital Transformation in the Indonesian Banking Industry: Impact on Employee Engagement. International Journal of Innovation, Creativity and Change, I2(4), $528-543$.

Zulkifli. (2012). Relationship Marketing Terhadap Customer Retantion dan Customer Loyalty Pada Naasabah Bank Mega, Tbk. Malang. Manajemen Dan Akuntansi, I(April), 55-68. 